\title{
Branchiobdellid size-crayfish size: a possible relationship
}

\author{
Mario MORI*, Yuri PRETONI, Sebastiano SALVIDIO and Andrea BALDUZZI \\ Dipartimento per lo studio del territorio e delle sue risorse (Dip.Te.Ris.), Università di Genova, C.so Europa 26, 16132 Genova, Italy \\ *e-mail corresponding author: mori@ulisse.it
}

\begin{abstract}
The aim of this paper was to verify a possible relationship between the size of the ectocommensal annelid Branchiobdella italica Canegallo, 1929 and that of its host, the freshwater crayfish Austropotamobius pallipes (Lereboullet 1858). 225 worms were collected from a crayfish population inhabiting a stream in central Liguria, north-western Italy. The sizes of B. italica ranged from 1 to $3.7 \mathrm{~mm}$ total length. The highest proportion of immature worms (41.7\%) was collected from juvenile crayfish (size-range $11-18 \mathrm{~mm}$ carapace length), $15 \%$ from subadult (19-26 $\mathrm{mm}$ ) and $3.4 \%$ from adult crayfish ( $\geq 27 \mathrm{~mm}$ ). The size-frequency distributions of worms from these three crayfish age groups differed significantly, except those from subadult and adult crayfish. It is arguable that the scarce presence of immature branchiobdellids on subadult and adult crayfish is due to the strong competition for space and food that these small worms have to withstand from co-specific adults.
\end{abstract}

Key words: symbiosis, Branchiobdella italica, Annelida, Austropotamobius pallipes, crayfish, Italy

\section{INTRODUCTION}

The leech-like Branchiobdellidae are members of the only parasitic family of the Clitellata Annelida (Gelder et al. 1999). They are exclusively ectoparasites or commensals of crayfish and a small number of other freshwater crustaceans (Alderman \& Polglase 1988). In Italian inland waters, the crayfish Austropotamobius pallipes (Lereboullet 1858) hosts five species of branchiobdellids (Gelder et al. 1994), but up to now, only Branchiobdella italica Canegallo 1929 and B. exodonta Gruber (1883) have been found in crayfish populations from Liguria (Mori et al. 2000). The former, which is more abundant, is an ectocommensal species living mainly on the external surface of the crayfish exoskeleton; the latter, which is uncommon, is an ectoparasite found primarily in the branchial chambers of crayfish (Gelder et al. 1994; Mori et al. 2000). In Ligurian crayfish populations, the rates of infestation of $B$. italica are independent of crayfish sex, and are greater in larger than in smaller crayfish (Mori et al. 2000). Furthermore, these authors observed that some crayfish populations hosted larger worms than others, suggesting that this diversity could be related to pollution of the streams, crayfish size, and season of collection. This research was designed to verify one of these hypotheses, i.e. whether there is a relationship between branchiobdellid size and crayfish size.

\section{MATERIAL AND METHODS}

The branchiobdellids were sampled from an A. pallipes population living in the Arvigo Stream, a small right tributary of the Bisagno Stream (central Liguria, north-western Italy). Using the method suggested by Gelder et al. (1994), the small worms were removed from the body of their hosts and placed in containers corresponding to one of three estimated age groups according to Mori et al. (1998): juveniles (size-range 11$18 \mathrm{~mm}$ carapace length), subadults (19-26 mm) and adults $(\geq 27 \mathrm{~mm})$. Crayfish carapace length (CL) was measured with a slide caliper from the posterior edge of an eye socket to the distal edge of the carapace. The branchiobdellids were fixed in the field in a $5 \%$ buffered solution of formaldehyde, and were then preserved in the laboratory in $70 \%$ alcohol and measured as total length (TL) to $0.01 \mathrm{~mm}$ using a dissection microscope equipped with an ocular micrometer.

Immature and mature worms were separated on the basis of the dimensions of their oocytes which, according to Bondi \& Facchini (1972), are mature at about 200 $\mu \mathrm{m}$.

Body-size distributions were analysed using the Kolgomorov-Smirnov two sample test, which contrasts cumulative step functions (cf. Siegel 1956; Conover 1971). This test is sensitive to differences in dispersion, skewness, and other scale parameters, and also to differences in location parameters, e.g. means and medians (Conover 1971).

A contingency table was used to examine differences in the distribution of frequencies of branchiobdellids from all three crayfish age groups (Sokal \& Rohlf 1981). The significance of differences between the percentages of juvenile or adult branchiobdellids from two different crayfish age groups was evaluated by means of a test of equality between two percentages (Sokal \& Rohlf 1981, p. 765)

\section{RESULTS AND DISCUSSION}

During this study, a total of 225 individuals of $B$. italica were collected and measured. A first sample of 
187 worms was recorded in spring 1999: 36 from juvenile, 100 from subadult and 51 from adult crayfish. A further sample of 38 branchiobdellids was collected from adult crayfish in the autumn of the same year.

A comparison of the size-frequency distributions of B. italica collected from adult crayfish in spring and autumn indicated that they were not significantly different in the two seasons (Kolgomorov-Smirnov two sample test, $\mathrm{D}=0.147, \mathrm{P}<0.001)$, so their sizes were pooled.

The size-frequency distributions of $B$. italica from the three crayfish age groups are shown in figure 1 . The size range of $B$. italica hosted by juvenile crayfish was 1-2.7 $\mathrm{mm}$, by subadults $1.1-3.3 \mathrm{~mm}$, and by adults $1.5-$ $3.7 \mathrm{~mm}$. The maximum worm dimensions measured in our study are in agreement with those found by Bondi (1962) in other branchiobdellid populations of central Italy. The size-frequency distributions of worms from the three crayfish age groups differed significantly, except for those in a comparison between subadults and adults (Tab. 1).
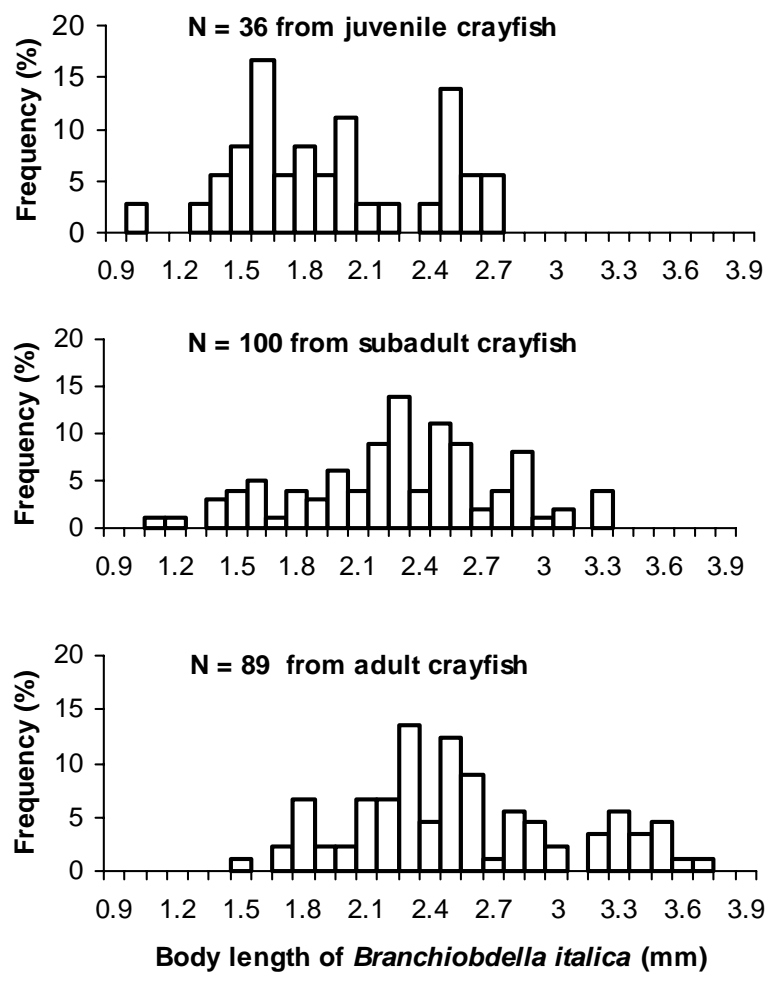

Fig. 1. Percentage size frequency distribution of individual Branchiobdella italica collected from three crayfish age groups.

In agreement with D'Angelo (1965) the maximum oocytes of $B$. italica measured about $350 \mu \mathrm{m}$. Most branchiobdellids (93\%) were found to attain sexual maturity at $1.8 \mathrm{~mm}$ total length. As shown in table 2, the highest proportion of immature worms (41.7\%) was collected from juvenile crayfish, while most of the mature worms were collected from adult crayfish (96.7\%).
An analysis of the data in table 2, performed by means of a contingency table, indicated that the branchiobdellid sizes were not distributed in the same proportion in the three crayfish age groups $\left(\chi^{2}=34.7, \mathrm{P}<0.01\right)$. A comparison at pairs between the percentages of immature and mature branchiobdellids from different crayfish age groups yielded significant differences among all the variables considered (Tab. 3). The present results show that immature branchiobdellids are mainly found on juvenile crayfish, with the mature worms being found on the adult crayfish.

Tab. 1. Comparison between size-frequency distributions (Kolmogorov-Smirnov two-sample test) of Branchiobdella italica from three crayfish age groups (Variables). P level, ***: P<0.001; ns: not significant.

\begin{tabular}{lcc}
\hline & \multicolumn{2}{c}{ Kolmogorov-Smirnov } \\
\cline { 2 - 3 } & $\mathrm{D}$ & $\mathrm{P}$ level \\
subadult $v s$ juvenile & 0.386 & $* * *$ \\
subadult $v s$ adult & 0.151 & $\mathrm{~ns}$ \\
adult $v s$ juvenile & 0.520 & $* * *$ \\
\hline
\end{tabular}

Tab. 2. Frequency (in percentage) of immature and mature branchiobdellids from three crayfish age groups.

\begin{tabular}{lccc}
\hline Crayfish & \multicolumn{3}{c}{ Branchiobdellids } \\
\cline { 2 - 4 } & $\begin{array}{c}\text { immature } \\
(\leq 1.7 \mathrm{~mm} \mathrm{TL})\end{array}$ & $\begin{array}{c}\text { mature } \\
(\geq 1.8 \mathrm{~mm} \mathrm{TL})\end{array}$ & Total number \\
\hline Juvenile & $41.7 \%$ & $58.3 \%$ & 36 \\
Subadult & $15.0 \%$ & $85.0 \%$ & 100 \\
Adult & $3.4 \%$ & $96.7 \%$ & 89 \\
\hline
\end{tabular}

Tab. 3. Comparisons at pairs between the percentages of immature and mature branchiobdellids from different crayfish age groups. Z: statistical value observed from the comparison between two percentages. $\mathrm{J}=$ juvenile; $\mathrm{S}=$ subadult; $\mathrm{A}=$ adult crayfish. $\mathrm{P}$ level, **: $\mathrm{P}<0.01$; ***: $\mathrm{P}<0.001$.

\begin{tabular}{|c|c|c|c|c|c|}
\hline \multirow{2}{*}{\multicolumn{3}{|c|}{$\frac{\text { Immature branchiobdellids }}{(\leq 1.7 \mathrm{~mm} \mathrm{TL})}$}} & \multirow{2}{*}{\multicolumn{3}{|c|}{$\frac{\text { Mature branchiobdellids }}{(\geq 1.8 \mathrm{~mm} \mathrm{TL})}$}} \\
\hline & & & & & \\
\hline variables & Z & P level & variables & Z & P level \\
\hline $\mathrm{J} v s \mathrm{~S}$ & 3.078 & $* *$ & $\mathrm{~J} v s \mathrm{~S}$ & 3.078 & ** \\
\hline $\mathrm{J} v s \mathrm{~A}$ & 5.237 & $* * *$ & $\mathrm{~J} v s \mathrm{~A}$ & 5.262 & $* * *$ \\
\hline $\mathrm{S} v s \mathrm{~A}$ & 2.462 & ** & $\mathrm{S} v s \mathrm{~A}$ & 2.491 & ** \\
\hline
\end{tabular}

There are several papers in the literature which demonstrate a positive relationship between parasite size and host size (see e.g. Van Damme et al. 1993; Bean \& Winfield 1992; Nieto \& Alberto 1994; Orecchia et al. 1999), while unfortunately nothing is known about the size relationship between a host and its ectocommensal.

Some speculation is therefore required to explain our results. The first question is why the mature branchiobdellids were found mainly on the subadult and adult crayfish. This pattern is probably linked to the crayfish moult that occurs several times a year in juvenile crayfish, once or twice in subadult and once in adult crayfish (Laurent 1988). Thus, the exoskeleton of 
subadult and adult crayfish probably offers the mature worms a substratum which is more stable and richer in food than that of juvenile crayfish (Mori et al. 2000). Further, during the moulting period the crayfish remains inside its refuge, cohabiting for several days with the old exoskeleton, until the new exoskeleton has become sufficiently tough. This behaviour means that the individuals of $B$. italica could easily transfer from the old to the new exoskeleton (Mazzarelli 1908), so that the mature branchiobdellids may have been attached to the same crayfish since their immature stage.

In contrast, the scarce presence of immature $B$. italica on subadult and adult crayfish appears surprising, since the wide surface of their carapace seems a favourable substratum for settlement. Their scarcity could be due to the strong competition for space and food that these small worms have to withstand from adult co-specifics. In fact, Vogt (1999) found diatoms, rotifers, detritus and chironomid larvae in the gastric contents of $B$. pentodonta, a congener ectocommensal species of $B$. italica. Thus, the immature $B$. italica may also become food items for co-specific adults. Hence, the immature branchiobdellids that settle on the body surface of juvenile crayfish increase their chances of survival. A habitat segregation between immature and mature $B$. italica due to predation from large individuals of the same species seems a reasonable hypothesis, since this situation exists for various species of fish (Mazzoni \& Caraschi 1995), crayfish (Mori et al. 1998) and salamanders (Salvidio et al. 1994).

\section{ACKNOWLEDGMENTS}

We wish to thank Dr. Giovanni B. Delmastro whose suggestion significantly improved this paper.

\section{REFERENCES}

Alderman, D.J. \& J.L. Polglase. 1988. Pathogens, parasites and commensals. In: D.M. Holdich \& R.S. Lowery (Eds), Freshwater crayfish. Biology, Management and Exploitation. Croom Helm, London: 167-212.

Bean, C.W. \& I.J. Winfield. 1992. Influences of the tapeworm Ligula intestinalis (L.) on the spatial distributions of juvenile roach Rutilus rutilus (L.) and gudgeon Gobio gobio (L.) in Lough Neagh, Northern Ireland. Neth. J. Zool., 42: 416-429.

Bondi, C. 1962. Osservazioni sull'apparato sessuale maschile in Branchiobdella pentodonta Withman. Riv. Biol., 55: 736.

Bondi, C. \& L. Facchini. 1972. Observations on the oocyte ultrastructure and vitellogenesis of Branchiobdella pentodonta Whitman. Acta Embr. Exper., 2: 225-241.

Conover, W.J. 1971. Practical nonparametric statistics. John Wiley and Sons, New York: 462 pp.

Received: February 2001

Accepted: July 2001
D’Angelo, L. 1965. Osservazioni sull'apparato riproduttore femminile in Branchiobdella pentodonta Whitman. Arch. Zool. Ital., 50: 29-39 + XII Tab.

Gelder, S.R., G.B. Delmastro \& M. Ferraguti. 1994. A report on branchiobdellidans (Annelida: Clitellata) and a taxonomic key to the species in northern Italy, including the first record of Cambaricola mesochoreus on the introduced American red swamp crayfish. Boll. Zool., 61: 179183.

Gelder, S.R., G.B. Delmastro \& J.N. Rayburn. 1999. Distribution of native and exotic branchiobdellidans (Annelida: Clitellata) on their respective crayfish hosts in northern Italy, with the first record of native Branchiobdella species on an exotic North American crayfish. J. Limnol., 58: 20-24.

Laurent, P.J. 1988. Austropotamobus pallipes and A. torrentium, with observations on their interaction with other species in Europe. In: D.M. Holdich \& R.S. Lowery (Eds), Freshwater crayfish. Biology, Management and Exploitation. Crom Helm, London: 341-364

Mazzarelli, G. 1908. Su di alcune malattie di pesci e gamberi osservate in Lombardia. Atti III Congresso Nazionale Pesca Milano, Milano 20 settembre 1906: 261-296.

Mazzoni, R. \& E.P. Caraschi. 1995. Size structure, sex ratio and onset of sexual maturity of two species of Hypostomus. J. Fish Biol., 47: 841-849

Mori, M., E. Rosso \& S. Salvidio. 2000. Presenza e incidenza delle Branchiobdelle (Annelida, Branchiobdellidae) nelle popolazioni astacicoli liguri. Ann. Mus. Civ. St. Nat. Giacomo Doria, Genova, 93: 211-224.

Mori, M., S. Salvidio \& P. Cresta. 1998 - Size structure, relative growth and sanitary condition of a crayfish population (Austropotamobius pallipes) living in rocky pools. Spixiana, 21: 135-144.

Nieto, P. \& L.J. Alberto. 1994. Presence of Anilocra frontalis H. Milne Edwards, 1840 (Isopoda, Flabellifera) on the southern Atlantic coast of the Iberian Peninsula: spectrum of parasitism and parasitic relationship with Gobius paganellus Linnaeus, 1758 (Pisces, Gobiidae). Crustaceana, 66: 67-77.

Orecchia, S., M. Mori \& F. Biagi. 1999. Note su Pseudione affinis G. O. Sars, isopode bopiride parassita del gambero Plesionika martia A. Milne Edwards del Tirreno settentrionale. Doriana, 7 (313): 1-10.

Salvidio, S., A. Lattes, M. Tavano, F. Melodia \& M.V. Pastorino. 1994. Ecology of a Speleomantes ambrosii population inhabiting an artificial tunnel. Amphibia-Reptilia, 15: $33-45$.

Siegel, S. 1956. Non parametric statistics for the behavioral sciences. McGraw-Hill, New York: 312 pp.

Van Damme, P.A., D. Maertens, A. Arrumm, O. Hamerlynck \& F.J. Ollevier. 1993. The role of Callionymus lyra and $C$. reticulatus in the life cycle of Lernaeocera lusci in Belgian coastal waters (Southern Bight of the North Sea). $J$. Fish Biol., 42: 395-401.

Vogt, G. 1999. Disease of European freshwater crayfish, with particular emphasis on interspecific transmission of pathogens. In: F. Gherardi \& D.M. Holdich (Eds), Crayfish in Europe as alien species. How to make the best of a bad situation? Crustacean Issues, 11: 87-103. 